\title{
Geri gelmeyen zamanın peşinde bir roman karakteri: Benjy Compson
}

\section{Ümit HASANUSTA1} APA: Hasanusta, Ü. (2020). Geri gelmeyen zamanın peşinde bir roman karakteri: Benjy Compson.
RumeliDE Dil ve Edebiyat Araştırmaları Dergisi, (19), 614-627. DOI: 10.2900o/rumelide.752566.

\section{$\ddot{\mathbf{O} z}$}

Bu çalışmada William Faulkner’in Ses ve Öfke adlı eserinin “7 Nisan 1928” başlıklı birinci bölümü, bir modernist anlatı olarak "zaman" ve "bilinç" kavramları bakımından incelenmektedir. Bu bölümde anlatı, zeka özürlü bir karakter olan Benjy Compson’un zihninden, Compson ailesinin tarihini yansıtmaktadır. Faulkner'ın romanındaki deneyselciliğin temelinde ise 20. Yüzyılda dünyada meydana gelen değişimler bulunmaktadır. Bu dönemde "gerçeklik" ve "doğru” kavramları üzerindeki tartışmalar ve bu kavramların tanımlarının değişmesi diğer bütün sanatlarda olduğu gibi edebiyatta da farklı anlatı yöntemlerinin ihtiyacını beraberinde getirmiştir, çünkü bu yeni gerçekliği geleneksel yöntemlerle anlatmak mümkün değildir. Bu çağda, özellikle William James, Henri Bergson, Sigmund Freud gibi bilim insanları ve düşünürler "zaman” ve "bilinç" kavramlarını sorgulamış ve bunlar için yeni tanımlar bulmuşlardır. Birçok modernist yazar da aynı şekilde eserlerinde bu kavramları sorgulamaya, hatta eserlerini, zaman ve bilinci merkeze yerleştirerek kurgulamaya başlamışlardır. William Faulkner'in Ses ve Öfke adlı eseri de zaman ve bilinç konusunda farklı anlatı yöntemleri üreten deneysel bir yapıt olarak modernist romanın önemli bir noktasıdır. Bu çalışmada öncelikle modernist romanın özellikleri ve anlatı geleneğine getirdiği yenilikler incelenecektir. Daha sonra da Faulkner'in yapitının özellikle Benjy Compson'un tecrübesini yansıtan birinci bölümüne odaklanarak, romanın biçim ve içeriğinin modernist anlatı yöntemleriyle ve "zaman ve bilinç” kavramlarıyla ilişkisi ele alınacaktır.

Anahtar kelimeler: Modernist Roman, Amerikan Romanı, Ses ve Öfke, William Faulkner, Benjy Compson, zaman ve bilinç

\section{A novel character in search of the past time: Benjy Compson}

\begin{abstract}
In this study, the first chapter of William Faulkner's novel Sound and the Fury, entitled "April 7th 1928", is studied as a modern narrative regarding the concepts of "time" and "consciousness". In this chapter, the narrative reflects the Compson family history through the mind of mentally retarded character Benjy Compson. Changes in the world during the 2oth century lie at the root of the experimentalism in Faulkner's fiction. In this period, discussions about the concepts of 'reality' and 'truth' and the changes in the definitions of these concepts brought the need of new narrative techniques just as all the other arts because it was not possible to represent this new reality with conventional techniques. In this age, especially philosophers and scientists such as William James, Henri Bergson, and Sigmund Freud questioned the concepts of "time" and "consciousness" and found new definitions for them. Likewise, many modern writers began to question these concepts and began to fictionalise their works locating "time" and "consciousness" in the center of their
\end{abstract}

1 Dr. Öğr. Üyesi, Biruni Üniversitesi, Eğitim Fakültesi, Yabancı Diller Eğitimi Bölümü (İstanbul, Türkiye), uhasanusta@gmail.com, ORCID ID: 0ooo-0002-8131-7661 [Makale kaylt tarihi: 13.02.2020-kabul tarihi: 20.06.2020; DOI: $10.29000 /$ rumelide.752566] 
works. William Faulkner's Sound and The Fury is an important point of modern novel which creates different narrative techniques on time and consciousness. In this study, first the features of modern fiction and the innovations it brought to narrative tradition will be rendered. Then the relationship of the form and content of the novel with modern narrative techniques and the concepts of "time and consciousness" will be evaluated mostly focusing on the first chapter of Faulkner's work which reflects the experience of Benjy Compson.

Keywords: Modern Novel, American Novel, Sound and the Fury, William Faulkner, Benjy Compson, time and consciousness

\section{Modernist roman: Neden, ne zaman ve nasıl?}

William Faulkner, Ses ve Öfke'yi okumaya başlayan geleneksel okuru daha en baştan şaşırtacak şekilde; metni, düz ilerlemek yerine zaman içinde ileri ve geri giden dört ayrı bölüme ayırırken alışılageldik roman geleneğine başkaldırmayı amaçlıyor olmalıydı, en azından roman bunu yapıyordu. Metin 7 Nisan 1928'de başlıyor, sonra on sekiz yll öncesine dönerek 2 Haziran 1910 gününü anlatıyor ve tekrar 1928 yllına, 6 Haziran 1928'e uğruyor ve 8 Haziran 1928 gününde tamamlanıyordu. Klasik romanın çizgisel ilerleyen olay örgüsünden daha en başta ayrılacağını vaat etmesi, okuru uyarması bakımından önemliydi; çünkü "zaman" kavramı roman boyunca bütün karakterlerce ve bütün bölümlerde sorgulanıyordu. Birçok modernist yazar gibi Faulkner yalnızca zaman kavramını sorgulamakla kalmıyordu romanda. Öncelikle Ses ve Öfke'yi dört ayrı günü anlatan bölümlere ayırmıştı. Bu bölümleri de her şeyden haberdar ve her şeyi bilen güçlü, otoriter yazar sesine anlattırmıyor, ya da her şeyden haberdar ve her şeyi bilen, güçlü, otoriter yazar olarak anlatmıyordu. Dördü de birbirinden farklı olan ve son bölüm dışında karakterlerin kendi tecrübelerini kendi kelimeleriyle anlattıkları, karakterlerin zihinlerine girilerek gerçekliği nasıl tecrübe ettiklerinin aktarılmaya çalışıldığı metinler yaratıyordu. Yani, zaman kavramının yanında "bilinç" kavramı da roman boyunca Faulkner'ın en önemli uğraş alanlarından biri oluyordu. Özellikle romanın birinci bölümünde, anlatı zihinsel özürlü Benjy Compson karakterinin zihninden aktarılıyor, böyle bir karakterin yaşadıklarını tecrübe edişi metinde yansıtılıyordu. Bu çalışmada da, Benjy Compson'un zihninden aktarılan anlatının, modernist deneyselciliğin önemli bir örneği olarak "zaman" ve "bilinç" kavramlarını sorgulayışı ele alınmaktadır. Compson ailesinin geçmişini böylesine güvenilmez bir anlatıcının zihninden kurgulayan Faulkner, metinde zamanın öznelliğini vurgulamakla beraber, bilincin karmaşıklığını ve bu karmaşıklığın yansımasını sağlayan dildeki parçalanmış yapıyı metnin ana özellikleri olarak ortaya koymaktadır.

Roman, edebi bir tür olarak ortaya çıktığında iddialarından belki de en büyüğü gerçekçi bir tür olmasıydı. Kendinden önce gelen edebi geleneğin aksine bu yeni tür, tümellere değil tikellere önem vereceğini vaat ediyordu. Günlük hayatta karşılaşılabilecek normal bir bireyin yaşantısının aktarımı olacaktı roman ve artık geleneksel olarak belirlenmiş tiplerden ziyade, yalnızca kendi hayatına ait koşullarda yaşayan bireylerle karşılaşacaktı okur bu yeni türde. Gerçeklikle kurduğu bu ilişki, romanın zaman kurgusu olarak da kendinden önce gelen diğer edebiyat türlerinden ayrılmasını gerekli kılacaktı. Daha önceki hiçbir türde, anlatının zaman boyutunun gerçek hayata uygunluğu bu kadar önemsenmemişti, ya da gerçeklik algısı romanın ortaya çıktığı zamanki gibi değildi. Ian Watt'ın da belirttiği gibi:

Zaman boyutu antik dönem, Ortaçağ ve Rönesans edebiyatında, romanda olduğundan çok farklı bir yöne sahiptir. Örneğin, tragedyalarda eylemin yirmi dört saate sığdırılması (şu meşhur zamanda birlik ilkesi), insan yaşamında zamansallık boyutunun gerçek anlamıla bir reddidir. Zira gerçekliği 
ezeli-ebedi tümeller çerçevesinde kavrayan klasik dünya görüşüyle uyum içerisinde kalarak, varlığa ilişkin hakikatin bir yaşam süresi boyunca olduğu kadar, bir günlük bir zaman diliminde de bütünüyle sergilenebileceğini ima eder." (Watt, 2007:25)

Aydınlanma çă̆ı felsefesinin ve Newton fiziğinin etkisini de temelinde barındıran 18. Yüzyıl romanında ise bireyin günlük yaşantısı detaylarıyla aktarılmaya çalışılırken, bu detayların en gerçekçi biçimde kurgulanmasında dönemin “zaman” tanımı büyük etkiye sahip olacaktı. Bu tanım Newton’un zamana dair cümlelerinden oluşuyordu: "Kesinlikle doğru ve matematiksel zaman, kendi kendine ve kendi doğası gereğince, dışarıdan hiçbir şeyin etkisi olmaksızın eşit ölçüde ilerler.” (Kern, 2003: 11). Herşey gibi zamanı da hiç şüphesiz dosdoğru ölçebilen bir bilim anlayışı dönemin düşünce yapısını ve sanatsal üretimlerini de etkilerken, bu düşünce yapısı romancıları da gerçekçi, gerçekliğine inandırıcı eserler yaratmak yönünde zorlamaktaydı. Romanların gerçek hayata benzemesi, "bireyin yaşamını hem geniş bir perspektifle tarihsel bir süreç olarak, hem de daha yakından bir bakışla, arka planında en geçici düşünce ve eylemlerin cereyan ettiği bir alan olarak sunmaları" (Watt,2007: 26), onların sahici olmalarını sağlayacaktı okurun gözünde. Yani, ortaya çıkışından itibaren bireyi ve bireyin kişisel düşüncelerini ve tecrübelerini, zamanı ve karakterlerin bu zaman içinde nasıl yaşadıklarını hep önemseyen ve kurgulanışında bütün bunları barındıran bir tür olmuştur roman ve İngiliz Edebiyatı'ndaki ilk örneklerini Daniel Defoe, Samuel Richardson ve Henry Fielding gibi yazarlara ait eserler oluşturmaktadır. Laurence Sterne'nin Tristram Shandy'si ise romanın bu ilk örnekleriyle on dokuzuncu yüzyılın realist romanı arasında duran ama özellikle zaman kurgusuyla bu iki geleneğe de uymayan bir yapıttır. Kendisinden iki yüzyıl sonra gelecek modernist yazarları müjdelercesine, Sterne zaman kurgusunu anlatısının tam da merkezine koyarak ve bu kurgunun bütün olanaklarından faydalanarak, gayet bilinçli bir tavırla modernist romana öncülük ediyordu Jale Parla’ya göre (Parla, 2000: 246). Karakterin doğumundan önce başlayıp ölümünden sonrasına taşıdığı anlatısıyla, zaman ve anlatıyla oldukça deneysel bir biçimde uğraşıyor ve belki anlatıdaki ya da romandaki zamansal gerçekliğin bir parodisini yapıyordu Sterne:

Gelgelelim, Sterne zaman sorununu ustalıkla ele almakla yetinmez ve bunu en uç mantıksal sonucuna kadar götürmeye çalışır: gerçekçi önermenin nihai noktası olan edebiyatla gerçeklik arasında birebir mütekabiliyet. Kahramanının uyanık geçirdiği her bir saat için bir saatlik okuma malzemesi tedarik etmek suretiyle, roman ile okurun romanı okuması arasında zamansal açıdan mutlak bir mütekabiliyet sağlamayı amaçladığını söyler. (Parla, 2000:36)

Michel Butor, "Değişik gerçeklere değişik anlatı biçimleri denk düşer” (Butor,1991:20-21) demiştir ve bu cümle, romanın ortaya çıkışı, daha sonra da on dokuzuncu yüzyll romanı ve modernist romana doğru evrilmesini açıklamak için çok uygun olabilir. Epistemolojik nedenlerden çokça etkilenerek, on dokuzuncu yüzyıl realist romanı, kendine sebep-sonuç ilişkilerinin çok önemli olduğu ve dün-bugünyarın şeklinde ilerleyen çizgisel zamana sıkı sıkıya bağlı anlatılardan oluşan bir gelenek yaratmıştır. Pozitivist dünya görüşünün ve Newton fiziğinin geçerli olduğu dönemde, gerçek dışarıdan bakılarak bilinebilmektedir ve realist roman, Stendal'ın tanımlamasına göre yol boyunca gidilirken etrafa tutulan bir aynadır, gerçekliği tamı tamına yansıtabilecek bir araçtır (Matz,2004: 33). Yıldız Ecevit’e göre:

19. Yüzyıl sonuna değin üretilen edebiyat ürünleri başı-sonu belli, kapalı yapıda metinlerdir. ( ... ) 19. Yüzyll romanının, nerede, ne zaman, nasıl ve neden sorularına neredeyse kesin yanıtlar veren biçim-içerik dokusunun, çağın gerçeklik anlayışıla birebir örtüştüğü söylenebilir. 19. Yüzyıl realist romanı Newton fiziğinin edebiyat estetiğindeki uzantısı görünümündedir. Çağın romancısı olayları zamandizinsel bir akış içinde, dün-bugün-yarın sıralamasına sıkı sıkıya bağlı kalarak öyküler. (Ecevit,2001: 23)

Modernizm öncesi, romanın hiç şüphe edilmeyecek bütünsel gerçekleri ve geleneksel görme biçimleri vardı. Yazarlar da bu varolan gerçekleri anlatmakta geleneksel yöntemlerin yeterliliğine inanıyor 
olmalıydılar, çünkü hala gelenekselleşmiş yöntemleri kullanıyorlardı yazarken. Hatta bazıları, Virginia Woolf tarafından materyalist olmakla suçlanacak biçimde, modern zamanlarda da bu yöntemleri kullanmaya devam edeceklerdi. On dokuzuncu yüzyılda gerçeğin bir yansıması olan ve gerçeklik ilüzyonu yaratması gereken roman (aslında diğer bütün türlerle birlikte), bu bütünsel ve herkes için aynı olan evrensel gerçekliği yansıtmak için tanrısal bakış açıları olan, herşeyi bilmeye muktedir ve de gayet güvenilir anlatıcıları kullanıyordu. Bu güçlü anlatıcılar bütün olayları şaşmaz bir bilgiyle, dümdüz bir zaman sıralamasıyla anlatıyorlardı. David Lodge'a göre, bahsi geçen bu anlatıcılar, sosyal olayları, gelişmeleri, çatışmaları tam manasıyla idrak etme ve ifade etme becerisine sahiptiler. Dış gerçeklik ve olay örgüsü yalnızca önemli değil, gerçeği anlamak ve yansıtmak için yeterliydi de (Lodge, 2002:50).

Ama modern çağa gelindiğinde, bu gerçeklik anlayışıyla birlikte gerçeği ifadelendirme biçimleri de ortadan kalkmak ve yerlerini yeni gerçeklik tanımlarıyla yeni ifade biçimlerine vermek zorunda kalacaklardı. Fakat şunu da belirtmek gerekir ki çoğunlukla realist romanın karşısında durur gibi görünen modernist roman, realist ve naturalist romandan da etkilenmiştir bazı noktalarda. Modernizmin realist romanı her anlamıyla tamamen reddetmesi yanlış bir çıkarım olmaktadır bu yüzden. Realist roman, dış gerçeklikten ziyade karakterin düşünceleri ve bakış açısını yansıtmaya önem veren Flaubert gibi temsilcileriyle modernist romana katkı sağlamış ve belki de modernist romanın en bilinen özelliklerinden "bilinç akışı”nın temellerinin atılmasına yardımcı olmuştur.

Yirminci yüzyılın modernist romanı birçok bakımdan roman geleneğine hem biçimsel hem de içerik olarak büyük bir başkaldırı niteliği taşır. Var olan geleneklerin kırıldığı, bozulduğu, yıllardır kullanılagelmiş anlatı yöntemlerinin artık işe yaramaz ilan edilip dönemin yazarlarının yeni yöntemler bulmaya çağrıldığı bir dönemdir bu yüzyıl. Sorun yalnızca edebiyatta değil, bütün sanatlardadır ve artık "yeni bir göz"dür ihtiyaç duyulan. Aslında modernizmin en temelinde yer alan sorun temsiliyetle ve gerçeklikle ilgilidir. Modern gerçeklik o kadar farklıdır ki eskilerden, artık neyin nasıl temsil edilebileceği ve anlatılabileceği sorgulanmakta ve bu eksikliği giderebilmek için yeni yöntemlere ihtiyaç duyulmaktadır; çünkü önceki yöntemler bu yeni gerçekliği temsil edebilmek için kifayetsizdirler artık. Lewis, bu modern temsil krizinin iki yönlü olduğunu ifade etmektedir. Bir tarafta neyin temsil edileceği varken, diğer tarafta da bu temsilin nasıl yapılacağı meselesi vardır. Diğer bir ifadeyle, sanatsal temsiliyet krizi hem biçimsel hem de içerikle ilgili bir krizdir (Lewis, 2007:2).

Yirminci yüzyldda, özellikle birkaç isim gerçeğin bu denli değişmesini sağlamıştır. Paul Ricoeur'ün "şüphenin ustaları" diye adlandırdığı Marx, Nietzsche ve Freud bu isimlerin oldukça başlarında bulunmaktadırlar. Bu üç isim de "insanın biyolojik bir varlık olduğunu ve yaptığı eylemlerin altında yatan bütün nedenlerden haberdar olmadığını" söyleyerek, gerçek kavramı ve onun temsilcisi olarak görülen dili soruşturarak, modernizmin geleneksel düşünce ve inançları sorgulayan ve bunları bozan yapısının temelini oluşturmuşlardır. Bireyselcilik ve Aydınlanma felsefesi eleştirilirken, Batı medeniyetinin ilerlemeci ve pozitivist düşünce yapısı da modernizmin karşısında durduğu olgulardan olmaktadır. Özellikle Nietzche ve onun "doğru" kavramını sorgulayışı, modernist sanatların bu kavrama bakışını oldukça etkilemiş ve doğrunun kişilere ve bakış açısına göre değişken olduğu, nesnel bir bakış açısının varlığının mümkün olmadığı inancını ortaya çıarmıştır (Matz, 2004: 22). Bu inanç, modernist romanda oldukça fazla görülen çoklu bakış açlarını, perspektif yöntemini, Ses ve Öfke'deki gibi tekrar tekrar anlatılan hikayeleri ve romanlarda dış gerçeklikten çok bireylerin önemsendiği modernist anlatıları getiren süreci büyük ölçüde etkilemiştir. 
"Doğru” kavramına karşı beslenen bu şüphe, modernizmin her alanında ve her aşamasında kendini gösterecektir. Birinci Dünya Savaşı ve bu savaşın sonuçlarının Batı medeniyetinin mutlak doğrularından kaynaklandığı inancı, savaş dönemi ve sonrası edebiyatının ortasına gerçekliğe dair sürekli bir şüphe duygusunun yerleşmesine etki etmiş gibi görünmektedir. Fakat sebep ne olursa olsun ( savaş, yerleşik geleneklerin insan üzerindeki kötü etkisi veya bilimsel, sosyal gelişmeler vb.), kesin olan şudur ki, artık bütün sanatsal ürünlerde tek bir mutlak gerçeğe dair inançsızlıkla beraber anlamın veya gerçeğin çoğaltılmasına yönelik bir çaba olacaktır. Gerçeğin bu şekilde sorgulanması, modern romanda realizmin dönüşmesini de sağlamış, şüpheye dayalı yeni bir realizmin meydana gelmesine neden olmuştur (Matz, 2004: 33).

Modernist romanın gerçeklikle kurduğu ilişkiden bahsederken, söz edilmesi en gerekli olan özelliği, kendinden önce oluşmuş roman geleneğinden apayrı bir biçimde dış gerçekliği reddederek bireylerin bu gerçekliği kendi içlerinde nasıl tecrübe ettiklerini gösterme çabasında oluşudur. Artık bireyin hayatı ya da zamanı nasıl tecrübe ettiğine dair çok farklı şeyler söylenmektedir, bilincin işleyişi eski insanların bildiğine hiç benzemeyecek biçimde tanımlanmaktadır, zaman "öznel” ve "kamusal" olarak ikiye ayrılmaktadır ve bu, kişisel zamanla birlikte kişisel tarih düşüncesini de beraberinde getirmektedir. Böylesine yeni gerçekliklerle karşı karşıyayken, artık Stendal'ın "geçtiği yola ayna tutma” yöntemi hiçbirşey ifade etmemektedir. Yani bundan böyle, romanın gerçekçi bir tür olma iddiasını sürdürebilmesi için yaratacă̆ı yeni anlatı yöntemleriyle varolan bu yeni gerçekliğe ayak uydurması gereklidir.

Virginia Woolf, "Modern Roman” yazısında, Arnott Bennett, H.G Wells ve John Galsworthy gibi yazarları önemsiz şeylerden söz etmekle suçlamıştır. Ona göre bu yazarlar, sundukları kişilerin iç dünyasında olup bitene en küçük bir ilgi duymamışlardı, tinin derinliklerini hiçbir zaman görememişlerdi. Sözgelimi, Woolf un Mrs. Dalloway'ine baktığımızda ise, romanın kurgusunu oluşturan en önemli öğe, kişilerin iç dünyaları, bilinçlerinin nasıl işlediği ve her bir bireyin dış gerçekliği algılamada nasıl farklılık gösterdiğidir. Roman bir günü bile doldurmayacak bir zaman diliminde geçer. Standart zamanın güçlü kudretli temsilcisi Big Ben’in saati haber veren vuruşları işitilir Londra'da, şehrin içinde gezinen Clarissa Dalloway'in zihninden geçenler ise Big Ben'in haber verdiği zamanın sınırlarına hiç uymayarak neredeyse bütün hayatını kapsamaktadır Clarissa’nın. İzlenimler bilince düşer düşmez onları yakalamak ister Woolf, gerçek tecrübeyi aktarabilmek için. Bilinç, modern gerçekliğin en önemli belirleyicilerinden olan şehrin tahmin edilemez çokluktaki uyarıcılarıyla ancak "bilinç akışı" ile mücadele edebilir. Zaman da geçmiş, şimdi ve geleceğin bütün sınırlarının kalktığı bir bütünlükte akmaktadır ve bütün bunlar, klasik romanın göndergesel diliyle hiç de karşılaştırılamayacak bir şiirsellikle anlatılır. Böylelikle Mrs. Dalloway, modernist romanın birçok özelliğini barındıran bir örnek oluşturur. Fakat bu bahsedilen zaman hiç de Newton'un tarif ettiği gibi mutlak biçimde dümdüz ilerleyen, birbirine eşit parçalara ayrılıp ölçülebilen, saatlerin tik taklarındaki gibi mekanik bir zamana benzememektedir. Aynı şekilde insan bilincinde de düşünceler ya da hisler "tren vagonları" gibi yan yana ve ayrı ayrı dizili durmamaktadırlar. Herşey ayrılmaz biçimde, aynen bir "nehir gibi” birbirine karışmıştır.

İnsan bilincinin bir nehrin akışına benzetildiği ilk kaynak William James'e aitti: Principles of Psychology (Psikolojinin İkeleri). James, eski tanımlamaların aksine, bilincin birbirinden farklı, ardı sıra dizilmiş parçalardan oluşmadığını iddia ediyordu ve bilince dair kendi tanımını anlatırken kullandığı metaforlar "bilinç akışı" (stream of consciousness) ya da "düşünce akışı"ydı (stream of thought) (Matz, 2004: 19). Ona göre, tıpkı bir nehir gibi akıcıydı bilinç ve içinde bütün imgelerin birbirine karıştığı, birbirini etkilediği ve artık parça parçalıktan ve durağanlıktan uzak sürekli bir akış 
halindeydi. Zihnin içine giren her şey, zaman farkı olmaksızın kendinden önce orada bulunanlarla bağlı hale geliyor, bu şekilde sürekli gelişen bir yapı oluyordu. Yani "zincir" ya da "tren" gibi kelimeler, bilincin doğasını anlatmak için kesinlikle yetersizdi James'e göre (James, 1950). Bu sürekli akış içinde dış dünyadan gelen bir imge ya da uyarıcıyı algılamak da bilincin bütününde yer alan her şeyle ilgili bir eyleme dönüşüyordu. Bu imgeyi algılamada bütün geçmiş tecrübeler etkili oluyor ve yeni uyarıcıyla birlikte bilinç yeni bir hal alıyordu. Erbora tarafından da tanımlandığı gibi, bilinç sürekli bir zihinsel sürece dönüşüyordu artık; çünkü insan zihni dış dünyadan imgelerle karşllaştı̆̆ında, bunların tek tek algılanmadığını, bunun yerine akışkan bir şekilde birbirlerine sürüklendiklerini, böylece yeni bir değer ve anlam kazandıklarını iddia ediyordu James (Erbora, 1997:8).

Bilinci bu şekilde tanımlaması sayesinde William James'in ismi yalnızca psikolojide değil, modernist romana, bilinç akışı romanına etkisinden dolayı edebiyat tarihinde de oldukça önemli olacaktı. James'in bilince dair söyledikleri, yapıtlarını "karakterlerin zihinlerinden geçen düşünce süreçleri" olarak kurgulayacak modernist romancılara teorik bir arka plan sağlayacaktı. Etkilediği ilk yazarlar da kardeşi Henry James ve laboratuarında çalışan, “otomatik yazma” deneyleri yapan Gertrude Stein'dir. $\mathrm{Bu}$ iki Amerikalı yazar, Amerikan roman geleneğinde ve Amerika’ya modernist deneyselciliğin gelmesinde oldukça etkili olacaklardır. Henry James hem bilinçle fazlaca uğraştığı için, hem de romanın bir sanatsal yapıt olduğuna dair iddiası ve bunu kanıtlama çabalarından dolayı, yalnız Amerikan geleneğinde değil, roman geleneğinin bütününde öncü bir yazardır. Karakterlerin zihinlerine girerek, gerçeği güvenilmez anlatıcıların sınırlı bakış açılarından göstermeye çalışarak ve zamanı durdurarak, genişleterek kurguladığı romanlarıyla Joyce'a, Woolf’a, Faulkner'a ve diğer modernist yazarlara öncülük etmiştir ve romanda bilinç akışının temellerinin atılmasında oldukça etkili olmuştur. Ondan sonra günden güne karakterlerin iç gerçekliği romancılar için dış gerçeklikten ve olay örgülerinden çok daha önemli olacaktır (Matz, 2004:16).

Avrupa'da modernizmin getirdiği değişim ve “modern deneysel estetik" üzerine kurulu sanatsal yapılar Amerika’ya biraz daha geç ulaşabilmiştir. Yirminci yüzyılın başında Amerika’nın geleneksel düşünce ve yaşam tarzları bazı noktalarda devam ederken kapitalizm ve yeni yaşam mekanı olarak şehir, gelenekselin karşısında duruyordu. Ama artık Amerika'nın püriten, soylu geleneği yavaş yavaş etkisini yitirecek ve endüstrileşmiş, paranın egemen olduğu bir toplumsal yapı hükümranlığını ilan edecekti. Kapitalizm ve şehirleşmenin getirdiği bu yeni durum, natüralizm ile kendine ifade alanı bulacaktı. Bu yüzden 189o'larda Avrupa'da natüralizmin sınırları oldukça daralmışken, Amerika'da hala söyleyecek şeylerinin olduğu görülüyordu (Ruland, Bradbury, 1992:225-226).

Amerikan romanında natüralizm etkisini 1920'lere kadar koruyacaktı ama Great Gatsby'nin ve The Making of Americans'ın basıldıkları 1925 yllı modernizmin Amerikan edebiyatıyla ilişkisi açısından önemli bir tarihti. Fakat Henry James geleneğinden gelip Faulkner’in deneyselliğine daha yakın olması bakımından Gertrude Stein öncelikle söz açılması gereken yazar gibi görünmekte. Modernizmin en belirgin sorgu alanlarından olan "dil" ve "bilinç," Stein'in öncelikle "otomatik yazma" deneylerinde ve yazdığı Three Lives, Tender Buttons ve The Making of Americans eserlerinin tümünün merkezinde yer alan ve sürekli sorguladığı kavramlardır. Stein'in yapıtlarında görülen dil, bütün geleneksel kalıplarından ve yapılarından arındırılmış, sürekli tekrarlardan ve bu tekrarların tekrarlarından oluşmuş, sözdizimi bozulmuş bir dildir. Çünkü ona göre, isimler, sıfatlar ve dilin diğer öğeleriyle gerçeklik arasında doğrudan bir bağ yoktur ve bütün bunlar aslında keyfi gösterenlerdir. Dilin gelenekselleşmiş kalıplarını kırmak, dile dair "zihinsel alışkanlıklarımızı" bozmak ister. Okuru sürekli tetikte tutacak, tehdit altında hissetmesini sağlayacak bir yazıdır amaçladığı; çünkü dilin bir ayna olmadığını ancak bu şekilde gösterebilmek mümkündür. Dili bir şeyler söyleme zorunluluğundan 
kurtarmaya dair çabasıyla ve hiçbirşeyin gerçekten tarif edilemeyeceğine dair inancıyla yaptığı deneyler, Picasso'nun resmine benzer bir yazı çlkarıyordur ortaya ve böylece, tam da modernizmin amaçlarıyla örtüşen bir biçimde, okurun dile “yeni bir göz”le bakmasını sağlayacaktır. Lehrer, Stein’in dilde neyi amaçladığını şöyle ifade etmektedir:

\begin{abstract}
Gramerinde 'teklemeler' ve 'alakasız kelime seçimleri' olan Tender Buttons'ı okumak genellikle insanın sabrını ölçmek için yapılmış bir deneye benzer. Stein’in derdi de tastamam budur. Cümlenin sınırlamalarını hissetmemizi, kendi zihinsel alışkanlıklarımızı sorgulamamızı ister. Hiç olmadı, bizi pasif kabullenmeden kurtarmak, dilin göründüğü kadar basit olmadığını göstermek ister. Bu nedenle cümlelerini alakasız sözlerle doldurur. Kendisini tekrarlar, sonra da tekrarlarını tekrarlar. Öznesi olduğunda yüklemi olmayan, yüklemi olduğunda da öznesi olmayan cümleler yazar (Lehrer, 2009:163).
\end{abstract}

Stein'in Henry James’in eserlerini sevdiğini söylemek pek şaşırtıcı olmamalı. "Gereksiz laflarla dolu, anlaşlmaz romanlar yazarak meşhur olan” James, bir öncüydü Stein için ve "yirminci yüzyllın edebi yöntemine uzanabilen ilk yazar"dı. Three Lives (Üç Hayat)'ın Melanchta'sında, karakterlerin zihinlerine girip onların kendi dilleriyle konuşmasını sağlayan James'in yöntemini daha ileri taşıyarak yazarın kişisel tarzını da ortadan kaldırmış, yalnızca karakterin tarzını, tavrını ortaya koymuştur. Görünürde yalnızca genç, tecrübesiz bir zenci kız vardır. Freidman'a göre, hikaye Melanctha'nın zihninden gelen dolaysız bir alıntı izlenimi verir (Freidman, 1955:53).

William James'in bilinç tanımıyla birlikte modernist yazarlara, yapıtlarındaki deneysel yöntemler için arka plan sağlayan diğer teorilerden muhtemelen en önemlileri izafiyet teorisiyle Newton'un zaman kavramının mutlak doğruluğunu ortadan kaldıran Einstein ve öznel zaman kavramını ortaya atarak saatlerin zamanı ölçebilme yeteneklerinin sorgulanmasını sağlayan Henri Bergson'a aittir. 19. yüzyılda standart zaman kabul edilirken, bunun temelinde Newton'un saatlere ve takvimlere sorgusuz sualsiz güvenen zaman tanımı bulunuyordu. Bu tanıma göre zaman, herkes için aynı olan ve dümdüz işleyen, ölçümü saatlerle mümkün olan bir kavramdı ve standart bir zaman, insanların hayatını kolaylaştıracaktı çünkü bu zaman insanların trenlere binmelerini, işe gitmelerini, aynı zamanda uyuyup aynı zamanda uyanmalarını sağlayacaktı. Fakat herkes için zamanın standartlaşması bu kadar sorunsuz mu olacaktı? Mesela Kafka için hiç de öyle değildi. Ona göre uyumak, uyanmak, hayatla başa çıkmak, aslına bakılırsa hayatın ilerleyişiyle başa çıkmak mümkün değildi, çünkü insanın iç saati ve dışardaki standart saat asla birbiriyle uyuşmuyordu (Kern, 1983:17).

Einstein, 20. yüzyll düşüncesini büyük ölçüde etkileyen teorisinde, Newton'un aksine zamanın izafi olduğunu, her zaman aynı şekilde ölçümünün mümkün olmadığını, zamanı tecrübe eden kişiye göre değişebileceğini iddia ediyordu. Hatta hız arttıkça yavaşlayan zaman, ışık hızına ulaşıldığında durabilirdi bile. Tek bir saatin varlığı ve zamanı ölçmesi, hiçbir zaman yeterli değildi bu yüzden. Bir sürü saat farklı şeyler söylese de doğru zamanı gösterebilirdi. Einstein’in teorisi, yirminci yüzyılın zaman kavramını değiştirmekle kalmıyor, aynı zamanda mutlak gerçekliklerin varlığını geçersiz kılarak modernist edebiyatın "bakış açısı", "perspektif" gibi yöntemlerine de yol gösteriyordu; çünkü artık modernist edebiyat herkes için farklı olan gerçekliklerle ilgilenirken, standart saatler ve gerçeklikler modernist romanın karakterleri için pek de işe yaramayacaktı. Einstein'ın izafiyet teorisiyle birlikte, modernist zaman düşüncesini etkileyen Henri Bergson'un dureé kavramı da, standart bir zamanla hiç uyuşmayacak türdendi. Aslında William James’in bilincin sürekli bir akış halinde olduğu şeklindeki açıklaması ile Bergson'un kişiliği ve zamanın tecrübe edilişini incelediğinde bulduğu tanım birbiriyle çok ilgiliydi ve yakın gözlemler içermekteydi. Bergson da kişiliği açıklarken sürekli bir akıştan bahsediyordu (a continuous flux), ve bu akış bir bütünlük anlamına gelmekteydi. Bergon'a göre, bir kişi zamanı tecrübe ederken, dün-bugün-yarın diye ayırmaz. Bütün bu zamanlar 
kişinin bilincinde bir arada bulunur ve ayrlmaz ve devaml gelişen bir bütünlük içindedir. Gerçek tecrübe, zamanın böylesine bir bütünlükte algılandığı, bütün zamanların ve tecrübelerin birbirine karıştığı, birbirinin içine geçtĭgi içsel zamanda, yani dureé olarak adlandırılan anlarda yaşanır (Ann Gillies,1996: 11).

Bergson, zamanı "psikolojik" ya da "kişisel zaman" ve "standart" zaman olarak ikiye ayırıyordu ve kişinin gerçek tecrübesinin kendi kişisel zamanında, yani iç zamanında yaşandığını belirtiyordu. Ona göre zaman ölçülebilir, parçalara ayrılabilir bir olgu değil, bir bütünlüktü. Bergson, en önemli hatanın "zamansal olan tecrübeyi uzamsal bir şey gibi anlatmaya çalışmak" olduğunu söylüyordu. İnsan, zamanı saatlerin parçalayıp dümdüz ilerleyerek gösterdiği gibi tecrübe etmiyordu hiçbir zaman. Modernist romanlarda da sonraları örnekleneceği gibi ardı ardına dizili dakikalar ya da saatler değil, birbirinin içine karışmış anlarla tecrübe ediliyordu zaman.

Bergson, dış gerçekliğin ya da herhangi bir uyarıcının algılanmasındaki süreçten bahsederken hafızanın, yani geçmiş tecrübelerin ve algıların önemini vurgulamaktadır. Bir şeyin algılanması yalnızca o anla ve o tek şeyle ilgili değildir, bütün bir bilinçle ve hafızayla ilgilidir. Algılama sürecinde zihnimizdeki bütün geçmiş öğeler bu sürecin içine girer ve bunun için dış gerçekliğin algılanması böylesine özneldir ve kişiden kişiye bu denli farklılık gösterir. Bergson hafızayı istençli ve istenç dışı olarak ikiye ayırmış ve birincisinin istendiğinde hatırlanabilecek öğeleri barındırdığını, istenç dışı hafızanın ise geçmişe dair bütün algıları barındırdığı halde buradaki öğelerin bilinçli olarak hatırlanamayacaklarını, istenç dışı bir yolla, belki bazı uyarıcıların tetiklemesiyle geri gelebileceklerini belirtmiştir. Bergson'un istenç dışı hafıza kavramı, Proust'un geçmişin hatırlanmasına dair bulgularıyla oldukça benzerlik göstermektedir. Ayrıca geçmişin insan zihninde sürekli kaldığı ve şimdiki zamanda etkili olduğu düşüncesi William James ve Bergson'da birbirine yakın ifadelerle tanımlanır. James için geçmişteki algının zamansal uzaklığı ya da yakınlığı şimdiye etkisi bakımından farklılık göstermektedir, fakat Bergson 'uzak' ya da 'yakın' gibi ifadelerin uzamsal ifadeler olduğundan böyle bir farklılı̆̆ın mümkün olmadığını düşünmektedir.

20. yüzyıla ait bu düşünceler ve kuramlar, artık insanları yeni bir gerçeklikle karşı karşıya bırakıyordu. Bütün bu bilimsel gelişme ve düşüncelerle birlikte diğer sanatların etkileri de modernist edebiyatta kendini gösterecekti. Mesela fotoğrafla birlikte gerçeğe birebir benzeyen bir resmin anlamsızlığı tartışlıp impresyonizm ve post-impresyonizm ortaya çıkıyor ve bakılan objeden çok o objeye bakanın tecrübesi önemli oluyordu. Sinemanın 'flashback'i ve 'montaj'ı da edebiyatta yazarların deneysel çalışmalarına yardım edecekti. Bütün bunlar modernist romanın ortaya çıkışı ve gelişimini etkileyen faktörler olacaklar ve bütün bunlardan dolayı, artık bilinç ve zaman eskisi gibi kurgulanamayacaktı. Romanda, mutlak bir gerçeklikten söz edilemeyecek, güvenilmez anlatıcıların sınırlı bakış açıları önemli olacak, ve elbette dil de artık eskisinden çok farklı şekillerde kullanılacaktı.

\section{Bir modernist roman karakteri olarak Ses ve Öfke'nin Benjy Compson'u}

Ses ve Öfke, Compson ailesinin en küçük oğlu Benjy'nin 7 Nisan 1928'de geçen anlatısıyla başlar ve okur için bu ilk bölüm çok büyük ihtimalle en zorlayıcı bölüm olacaktır ilk okumada. Benjy, edebiyat tarihindeki en tuhaf ve en deneysel karakterlerden biri olmalıdır; çünkü Faulkner romanın bu ilk bölümünde zeka özürlü bir karakterin zihnini açığa çıarmaya uğraşarak ve bununla geleneksel olan anlatı kurallarıyla birlikte klasik zaman mantığını da ihlal ederek okuru genelde alışık olmadığı bir okuma tecrübesine götürecek bir anlatı ortaya çıkarmıştır. 
7 Nisan 1928 tarihinde Benjy Compson'un bahçede zenci hizmetçilerinin oğlu Luster ile birlikte gezinmesiyle başlar anlatı. Okur burada, Benjy'nin oldukça basit bir dille şimdiki zamanı-yani karakterlerin içinde bulundukları zamanı- anlatmasına tanıklık eder. Cümleler çok kısadır ve anlatılanlar Benjy'nin dış dünyada gördüklerinden ve yaptıklarından ibarettir.

Parmaklığın arkasında, sarmaşıkların arasından, vurduklarını görüyordum. Bayrağın olduğu yere geliyorlardı ve ben yürüdüm parmaklık boyunca. Dutun çevresindeki otların içinde aranıyor Luster.

Bayrağı çıkardılar, vuruyorlardı. Sonra bayrağı yeniden diktiler, tablaya gittiler, vurdu, öteki de vurdu. Sonra yine vurdular ve ben yürüdüm parmaklık boyunca.” (Faulkner, 2009:7).

Anlatı şimdiki zamanda devam ederken, okur hem Benjy'nin dış dünyada olan biteni anlatmasını, hem diğer insanların konuşmalarını ve Benjy’ye söylediklerini okuyacaktır romanın bu ilk bölümü boyunca. Anlatı zamanı içinde Benjy'nin yanında en fazla bulunan kişi Luster'dir ve en çok onun sesini duyarız Benjy ile konuşurken. Başkalarının söylediği cümleler veya diyaloglar Benjy'nin zihninden söylendikleri halleriyle aktarılmaktadır. Benjy'nin zihni, cümlelere ve diyaloglara hiçbir şekilde müdahale etmiyor ya da hiçbir değişikliğe uğratmıyor gibi görünmektedir. Yalnızca "dedi", "söyledi" gibi aktarma ifadeleri eklenmektedir cümlelere: "Hadi', dedi Luster. 'Artık baktık, Gelmiyorlar işte. Dereye dönelim de o kerata zenciler bulamadan biz bulalım çeyreği” (Faulkner,2009:7). Benjy, konuşma yetisinden yoksundur ve diş dünyada yanında olduğu insanlar onunla hiç konuşamamaktadırlar. Duydukları tek şey Benjy'nin sürekli olarak bağırmasıdır ve insanlar da sürekli ondan bunu kesmesini istemektedirler. Yani, dışarıdan bakıldığında zeka özürlü, sürekli inleyip rahatsız edici sesler çıaran, kocaman bir adamdır Benjy. Böyle bir karakterin zihninin içine girmek ve gerçeği nasıl tecrübe ettiğini görebilmek de büyük ihtimalle yalnızca modernist romandan sonraki edebiyat okurunun yakalayabileceği bir şanstır.

Faulkner, daha romanın en başından zaman meselesiyle ne kadar uğraşacağını ve bu kavramın Ses ve Öfke'de nasıl önemli olduğunu göstermek ister gibi-ki metni zamansal açıdan dört ayrı bölüme ayırması da buna işarettir- Benjy'nin anlatısının geçtiği günü tam da onun otuz üçüncü doğum günü olarak kurgulamıştır. Takvimlerin işleyişine göre otuz üç yaşına giren Benjy, aslında kendi özel zamanına göre hala üç yaşındadır. Saatler, günler ve yıllar, Benjy için standart zamanın söylediği gibi düzenli biçimde ilerlememişlerdir ve doğumundan beri geçen otuz üç yıla rağmen, Benjy Compson'un kişisel zamanı bundan çok farklıdır.

“Bana bak,' dedi Luster. 'Sakın sesini çıkarayım deme.'

Yine neden vızldanıyor seninki.'

'Ne bileyim ben,' dedi Luster. ‘İşte böyle esince aklına başlıyor vızıldanmaya. Sabahtan beri hiç durmadi. Bugün doğum günü de ondan galiba.'

'Kaç yaşında.'

'Otuz üç,' dedi Luster. 'Bu sabah bastı otuz üçüne.'

Sen otuz yıldır hep üç yaşında mı demek istiyorsun.'

'Ben annem ne söylerse onu söylerim,' dedi Luster. (Faukner, 2009:18)

Benjy ile Luster hala insanların golf oynadığı alana yakın yerlerde gezinirken ve anlatı şimdiki zamanda devam ederken çiti aşıp bahçe tarafına geçmeye çalışmaları, büyük ihtimalle çağdaş okurun bile bir an duraksayıp şaşırmasına neden olacak bir noktaya götürür anlatıyı: "Dur bir dakika', dedi Luster. 'Takıldın yine çiviye. Geçemezsin bir türlü şu çiviye takılmadan” (Faulkner,2009:8). 
Benjy'nin çiviye takılmasıyla birlikte yazılar italik olarak devam etmeye başlar, bu ilk bakışta zor farkedilebilecek bir değişimi de haber verir metinde: şimdiki zamanda Benjy'nin zihninde devam eden anlatı geçmişe dönmüştür ve Benjy geçmişi hatırlamaya başlamıştır. İtalik yazılar artık şimdiyi anlatmıyor, Benjy'nin geçmişe dair hatırladıklarından oluşuyordur. Caddy ve Maury dayı birden hikayeye girmiştir. Garip olan şudur ki, Benjy'nin bilincindeki zaman ve bununla birlikte hikayenin zamanı değiştiği halde, Benjy’nin zaman kiplerini kullanımında bir değişiklik olmamıştır. Şimdiki zamanda yaşadıklarını nasıl fiil çekimleriyle anlatıyorsa, geçmişe dair anımsadıkları da aynı şekilde aktarılmaktadır.

Caddy beni kurtardı ve sürünerek geçtik oradan. Maury Dayı kimse sizi görmesin demişti, biz de sürüne sürüne geçeriz oradan daha iyi, dedi Caddy. Eğil, Benjy. Bak iște böyle, görüyor musun? Eğildik ve geçtik bahçeden, çiçekler daladılar bizi ve hışırdadılar biz yürüdükçe. Toprak katıydı. Parmaklığa tırmandık, domuzlar homurdanıyor ve kokuyorlardı. Bügün canları pek sıkkın, içlerinden biri kesildi de, dedi Caddy. Toprak katıyd, basılmış ve düğüm düğüm (Faukner, 2009:8).

Çiviye takılmak Benjy'nin zihnini şimdiki zamandan geçmişte yine çiviye takıldı̆̆ı ve Caddy'nin onu kurtardı̆̆ı başka bir zamana götürmüştür. Çivi, geçmiş bir zamanın geri gelmesine yardımcı olmuştur. Fakat bu paragrafla birlikte okur için zor olan kısım başlamıştır. Bundan sonra, Benjy'nin bilinci sürekli şimdiki zaman ve birbirinden farklı birçok geçmiş zaman arasında gidip gelecektir. Bazen büyükanne Damuddy'nin öldüğü günün akşamı olacaktır bu, bazen Caddy'nin evlendiği gün, bazen de ismi Maury iken Benjy olarak değiştirdikleri zaman olacaktır. Farklı geçmiş zamanlar ve şimdi arasında Benjy'nin bilinci gidip gelirken, kafası karışık ve bu parçalardan bir bütünlük oluşturmaya çalışan okurun çabası boşa gidebilir bu durumda, en azından kitabın diğer bölümlerindeki diğer kardeşlerin anlatılarına gelene kadar sabretmesi gerekebilir. Benjy'nin zihninden kronolojisi ihlal edilmiş bir sürü zaman, bir sürü ses gelip geçecek ve okur Benjy'nin zihninde bütün seslerin bir arada olduğu bir 'karnavalda' hissedebilecektir. Ama bu zamanlar neden ve nasıl böylesine karışabilmektedir Benjy'nin bilincinde, nasıl işlemektedir bu bilinç ve zamanı nasıl algılar?

Birçok eleştirmen, Benjy'nin zaman algısının olmadığı görüşündedir. Yani, şimdiki zamanda Luster'le yürüyorken de, oradan zihni geçmiş zamana dönüp Caddy'nin onunla konuşmasını ya da Caddy'nin ağaca çıkıp Damuddy'nin öldüğü gün evde olanları izlediği zamanı hatırlıyorken de aynı zamanı yaşıyordur. Geçmişi hatırlamak, o anı aynen yeniden yaşamak anlamına geliyordur Benjy için. Geçmişşimdi-gelecek diye zamanı ayıramadı̆̆ından, sanki bölünmemiş, geniş, yekpare bir zamanda yaşıyordur Benjy. Bilinci zamanlar arasında geçiş yaptığında ve bir zamandan başka birine geçtiğinde kullandığı dilde hiçbir farklılık olmamasının nedeni de aslında zaten bu zamanlar arasında farklılık görmüyor oluşundandır. Sürekli devam eden bir şimdiki zamandır Benjy'nin yaşadığı, geçmiş ya da gelecek diye birşey yoktur onun için. 1950'lerde romanla ilgili yazan Perrin Lowley, Benjy'de zaman algısı bulunmadığını belirtirken, Cleanth Brooks da bu eksikliğin Benjy'nin sebep-sonuç ilişkisi kuramamasına, tecrübelerini zamansal ya da mantıksal olarak düzeneyememesine neden olduğunu ifade etmiştir (Burton, 1995:209).

Benjy'nin zamanı algılayışındaki farklılık, hatta zamanı hiç algılayamaması bir eksiklik ya da kötü bir durum gibi görünmektedir. Fakat belki de Bergson'un sözünü ettiği, sürekli bir bütün halinde akan ve geçmiş-gelecek diye ayrımlar kabul etmeyen zamandır Benjy'ninki. Aslında şunu da hatırlamak gerekir ki, Bergson bu şekilde tarif ettiği dureénin içinde geçen sürekli bir yaşantının da bir tür sorun anlamına geldiğini belirtmektedir. Çünkü insanlar dış gerçeklikle de ilişki kurmak zorundadırlar ve bunu sağlamak için içsel zamandan çıkıp uzamsal tariflerle belirlenen zamana geçmek gereklidir. İki zamanın birlikte uyum içinde bulunduğu bir kişiliktir ideal olan ona göre. 
Benjy’nin zihninin zamanlar arasında geçiş yapmasını sağlayan şey, genellikle çağrışımlardır. Bir yer, bir isim veya bir nesne geçmişteki bir olayı çağrıştırıp karakterin zihninin o hatırladığı ana gitmesini sağlamaktadır. Mesela Luster'la çiti geçerken çiviye takılmak geçmişte Caddy ile birlikteyken yine çiviye takıldığı bir ana götürür onu. O soğuk günde Caddy'nin "ellerini cebine sok" demesiyle Versh ve Maury Dayı ile birlikte Caddy'nin okuldan gelmesini bekledikleri başka bir soğuk güne gider. Luster'la birlikte arabalığa doğru ilerlemeleri yine başka bir zamanı, T.P’nin annesiyle onu Quentin ve babasının mezarına götürmek için arabayı sürdüğü bir günü hatırlatır. Aynı şekilde, geçmiş zamanda bir olayı hatırlarken Benjy'nin zihni, yine çağrışımla başka bir geçmiş olaya yönelebilmektedir. Bayan Patterson'a Maury Dayı'nın mektubunu götürdüğü iki ayrı olay, aynı zamanda gerçekleşmemiş olmalarına rağmen, Benjy bunları ard arda hatırlar. Patterson'lara mektup götürdüğünü anımsaması, bu karakterleri içeren diğer bir olayı çağrıştırmaktadır zihninde:

Sen bekle burada,' dedi Caddy. 'Şurackkta bekle, hemen gelirim. Mektubu ver bana.' Mektubu cebimden aldı. 'Ellerini ceplerinden çıkarma.' Elinde mektup, parmaklığı tırmandı ve hışırdayan kahverengi çiçeklerin arasından yürüdü. Bayan Patterson geldi, kapıyı açtı, önünde durdu.

Bay Patterson yeşil çiçeklerin içinde odun yarıyordu. Biraktı ve bana baktı. Bayan Patterson bahçeden geldi, koşa koşa. Gözlerini görünce başladım ağlamaya. Aptal, dedi Bayan Patterson, ona kaç kere söyledim yalnız başına göndermeyin bunu buraya diye. Ver bakayım onu bana çabuk. Bay Patterson hızlı hızlı geldi, elinde çapasılla. Bayan Patterson parmaklıktan eğildi, elini uzatarak. Parmaklığa tırmanmaya çalışıyor. Ver onu bana, dedi, ver onu bana. Bay Patterson parmaklığa tırmandı. Mektubu aldı. Bayan Patterson'un elbisesi parmaklığa takıldı. Yeniden gördüm gözlerini ve yamaçtan aşağıya koşmaya başladım (Faulkner, 2009:16).

Benjy'nin zihni geçmişe gittiğinde okur geçmişe dönmüş bir zihnin zamanıyla meşgulken anlatının şimdisinde olaylar devam etmektedir. Faulkner karakterlerin zihinlerini geçmişe döndürürken anlatı zamanını da durdurmaz. Luster'la Benjy dolaşmaya devam ederler ve sonra Benjy'nin zihninin şimdiki zamana geri dönmesi ise birinin ona bir şeyler söylemesiyle gerçekleşir çoğu kez. Zihin geçmişte gezinirken Luster'ın konuşmaları onun içinde bulundukları zamana dönmesini sağlar. Benjy geçmişte hatırladıkları şeylerden dolayı bağırmakta ve ağlamaktadır birçok zaman, ama Luster buna bir anlam veremez. Metnin şimdiki zamana dönüşü, Luster'in Benjy'den bağırmamasını istediği konuşmalarla başlar bu yüzden birçok defa:

“ 'Kaçarım hem bir daha gelmem', dedi Caddy. Ağlamaya başladım. Caddy döndü. 'Sus ağlama', dedi. Ben de sustum. Sonra derede oynadılar. Jason da oynuyordu. Derenin aşağılarında yalnız başına. Versh çalılığın arkasından çıktı, beni alıp yeniden suya götürdü.

Caddy’nin her yanı ıslanmış, arkası çamurlanmıştı. Ağlamaya başladım o zaman ben, Caddy geldi ve suda çömeldi.

“ ‘Sus’ dedi. 'Kaçmayacağım.’ Ben de sustum. Caddy yağmurda ıslanan ağaçlar gibi kokuyordu.

"Yine neyin var, dedi Luster. Şu zırıltıyı kesip sen de adam gibi suda oynasan olmaz mı?" (Fulkner, 2009:20)

Zeka özürlü, konuşamayan, sebep sonuç ilişkileri kuramayan ve zaman algısıdan yoksun Benjy'nin geçmişe ait olayları anımsarken ve zihninde yeniden yaşarken nasıl bu kadar detayı saklayabildiği ve hatırlayabiliğinin görülmesi ise şaşırtıcıdır. Morris Beja, Benjy’nin zamansızlığını ve geçmişi böylesine detaylı bir biçimde hatırlamasını açıklarken, durumu Freud'un The Unconscious (Bilinçdışı)'ta "bütün biliçdışı sistemlerin zamandan yoksun” olduğunu söylemesiyle ilişkilendirerek Benjy'nin zamansız oluşunu çoğunlukla zihninin bilinçdışı aşamada olmasına bağlar. Aynı zamanda burada kronolojik zaman dizimi algısı olmamasına rağmen, hafıza bilinçlilik durumundan bile daha iyi çalışabiliyor ve çok daha fazla detayı anımsayabiliyordur. Hatta o kadar güçlüdür ki bu anımsadığı geçmiş, Benjy şimdiyle arasında hiçbir ayrım gözetememektedir (Beja, 1971:184-185). 
Benjy'nin Caddy ile ilişkisi diğer hiçbir insanla olmadığı kadar yakındır. Çünkü Caddy gerçekten onunla iletişim kurmuş ve bir dil vadetmiştir Benjy'ye. Kendisi için Caddy'nin yeri bu kadar önemliylen, onun eksikliği de çok büyüktür bu yüzden Benjy için. Ama Stacy Burton’a göre Benjy geçmiş zamanları hatırlarken onları tam anlamıyla yaşadığını hissettiğinden Caddy'nin yokluğunu yalnızca tamamiyle şimdiki zamana bağlı olduğu anlarda hissetmektedir ve bu yüzden bu zamanlarda sürekli bağırmaktadır. Geçmişte Caddy'nin olduğu zamanları hafızasında yeniden yaratırken ise böyle bir eksiklik hissetmez (Burton, 1995: 122).

Geçmişe ait olaylar, Benjy'nin zihninden geçerken bütün karakterler ve hatta bu karakterlerin birbirlerine ve Benjy'ye söylediği her şey ayrıntılarıla zihinde yeniden üretilmektedir. Benjy'nin bilinci, sanki bir kamera gibi kaydetmiştir bütün anları ve tekrar gösteriyordur. Yalnızca durumlar ve konuşmalar görülür ve Benjy bunlara hiçbir müdahalede bulunmamakta veya hiçbir yorum yapmamaktadır; çünkü yorum yapma ve olayları bir düzene koyma yeteneğinden yoksundur. Bu durum bazı eleştimenlerin gözünde Benjy'yi modernist romanın hiç de hoşlanmadığı "güvenilir anlatıcı" konumuna getirmektedir. Onlara göre, gerçeği ondan daha nesnel biçimde aktarabilecek bir anlatıcı olamaz. Benjy'nin sınırlı bir gerçekliği bildiği belki doğrudur, ama doğumundan beri Compson ailesinin başından geçenleri aktarabilecek en güvenilir dil Benjy'nin dilidir. Sözgelimi, Karen Kaivola Benjy'nin bir tarih inşa edemediğini, hikaye anlatamadığını ya da olaylara anlam yükleyemediğini belirtir. Ross ise, Benjy'nin monoloğunu ideal bir anlatıcı parodisi olarak okumaktadır, çünkü Benjy anlamlarını farkedemese de bütün diyalogları hiç bozmadan, kusursuzca kaydetmektedir (Burton, 1995:210).

Ama Benjy'nin zihni kamera gibi her şeyi kaydeder ve sonra da gösterir mi sahiden? Aslında öyle değil. Çünkü Benjy'nin anlatısına bakıldığında bir gün içinde hep birkaç zamanın içinde gidip geldiği görülmektedir. Rastgele değildir zihninden geçenler, bir seçim vardır anlatısında. Zihninden geçen ve metni oluşturan olayların hepsi hayatında önemli zamanlara aittir. Çoğunlukla kendisi hakkında konuşmaların olduğu ve Caddy ile ilgili zamanlardır bunlar. Yorum yapma becerisinden ve zamanı algılamadan yoksundur belki Benjy ama yaşadığı olaylar arasında seçim yapabilmekte ve onun için önemli olan olay ve durumları yeniden yaratmaktadır zihninde (Burton, 1995:216).

Anlatının aktarıldığı Benjy Compson'un bilinci, olayları kronolojik bir sıraya koyamıyor olsa da, ya da geçmiş-şimdi-gelecek diye zamanları ayıramıyor ve hepsini bir bütünlük içinde görüyor olsa da, hiçbir şekilde olayları düzenleme çabasının olmadığını söylemek zordur. Öncelikle Benjy, anlattı̆̆ı olaylar arasında "ve", "sonra", "hala" gibi zamansal ifadeler kullanmaktadır. Bu, onun bir düzen oluşturma çabası içinde olduğunu göstermektedir: "T.P hala gülüyordu. Yere çöktü ve güldü. 'Vaaayy', dedi. 'Benjy ile düğüne gidiyorduk. Sasprilla içmeye,' dedi T.P” (Faulkner, 2009: 22). Ayrıca, geçmişte yaşadığı olayları tarihi sırayla hatırlamıyor olsa da hatırladığı olayları anlatmaya başladıktan sonra, başka bir yerde yine o zamana döndüğünde anlattıklarının öncesiyle değil, sonrasıyla devam eder. Mesela Damuddy'nin öldüğü günde geçen olayları farklı zamanlarda farklı parçalar halinde hatırlar. Ama bu parçalar aklına gelirken sonraki olay önce anlatılmaz, meydana geldikleri sıra takip edilir. Önce Benjy, Caddy ve diğer çocukların havuzda suda oynaması anlatılır, sonra Versh Caddy'nin elbisesini çıkarır ve Quentin buna kızar, Roskus çocukları yemeğe çă̆ırır, evin oraya gittiklerinde ışıklar yanıyordur ve neden olduğunu merak ederler, yemek yerler, sonra Caddy ağaca çıkar ve neler olduğunu öğrenmek için pencereden içeri bakar. Son olarak da yatmaya giderler. Bu olaylar farklı yerlerde Benjy'nin aklına geliyor olsa da meydana geldikleri sıra bozulmamaktadır (Burton, 1995:211). Bütün bunlar, Benjy'nin hiç de kamera gibi yalnızca kaydeden ve sonradan kendinden hiçbir şey katmaksızın gösteren bir anlatıı olmadığını işaret etmektedir. Benjy için de önemli olan şeyler vardır 
ve olayları bunlara göre düzenleme çabası içindedir. Zaten modernist roman, artık güvenilir bir anlatıcının olabileceğine dair inanca sahip bir tür değildir. Hiçbir anlatıcı güvenilir değildir artık modern çă̆da.

Dış dünyayı Benjy'nin diğer insanlardan ne kadar farklı tecrübe ettiğini görmek de okur için farklı bir okuma deneyimi sunar. Özellikle anlatının bazı bölümlerinde, mesela Caddy’nin düğününde Sasprilla içerken ya da birisi ona yemek yedirirken bunu daha açı şekilde görmek mümkündür. Normal bir bireyin çok farklı deneyimleyeceği ve önemsenmeyecek küçüklükte görünen bir olay yabancılaştırıcı bir etkiye sahip olabilir onun anlatımında. Hatta bazen Benjy'nin zihninde ve anlatımında, kendi uzuvlarını ya da sesini sanki başka birine aitmiş gibi hissettiği görünür. Sasprilla içerken hissettikleri, başına gelen şeyleri anlamlandıramayan bir hayvanın bunu tecrübe edişi gibidir sanki:

Beni tuttular. Çenemde, gömleğimde sıcak. 'İç', dedi Quentin. Başımı tuttular. İçimde sıcak ve ben yeniden başlıyorum. Bağırıyorum. Birşeyler oluyordu içimde ve ben daha çok ağllyordum, bir şeylerin oluşları kesilinceye kadar beni tuttular. Sonra sustum. Hala dönüyordu, sonra biçimler başladılar. 'Sandığı aç, Versh'. Yavaş yavaş geçiyorlardı biçimler. 'Şu boş torbaları yere yay.' Daha hızlı geçiyorlardı, hemen hemen yeterince hızlı. Şimdi kaldır ayağını şunun yerden. Geçtiler, düz ve aydınlık. T.P’nin güldüğünü işitiyorum. Ben onunla birlikte gittim, aydınlık yamaca çıtım (Faulkner, 2009: 23).

Benjy'nin anlatısı ilerledikçe, metinde zamanlar arasındaki geçişler ve bunların yansıtılmasıyla ilgili dikkat çekici bir farklılık ortaya çıkmaktadır. Metnin başlarında geçmişten hatırlanan zamanların birbirleri arasındaki geçişler okur tarafından rahatça ayırt edilebilirken, sonradan bu geçişler arasındaki belirginlik oldukça azalmaktadır. Metnin ilerleyen bölümlerinde, geçmişe ait bu zamanların çok daha fazla birbirine karıştığı, daha anlaşılmaz bir dil ile anlatıldığı ve iki olay ya da zaman arasındaki sınırların iyiden iyiye yok olduğu görülmektedir. Geçmiş ve şimdi arasında gezinirken, zihnin iki zamanda da kaldığı süreler artık çok daha kısalmıştır. Bu durum özellikle Benjy dışarıdan eve döndükten sonra belli olmaktadır ve evdeki insanların ve bununla beraber dış uyarıcıların çoğalması geçmişi hatırlarken çok daha çabuk şimdiye dönmesine neden oluyor gibi gözükmektedir.

Bu gece ben yedireyim ona," dedi Caddy. 'Versh yedirdiği zaman ağlıyor.'

'Tepsiyi al', dedi Dilsey. 'Git de Benjy'ye yemeğini yedir.' 'Caddy'nin yedirmesini istemez misin', dedi Caddy.

Bu pislik terlik ille de masanın üstünde mi duracak, dedi Quentin.

Yemeğini neden mutfakta yedirmiyorsunuz ona. Domuzlarla birlikte yesek daha iyi olacak.

Ĕ̆er bizim yemek yiyişimizi beğenmiyorsan sofraya gelme, dedi Jason.

Roskus'tan dumanlar çıkıyor. Sobanın önünde oturuyordu. Fırının kapağı açık... (Faulkner, 200o9: 33).

Benjy'nin bölümü, sürekli olarak devam eden ileri-geri atlamalarla, döngüsel biçimde ilerleyip aynı olayların tekrar tekrar üstünden geçilerek oluşturulan bir anlatı meydana getirmektedir ve bu yapısıyla çok uzun bir hikaye zamanını kapsamaktadır. Benjy'nin hikayenin bütününde bıraktığı boşluklar ise romanın diğer bölümlerindeki anlatıcılar tarafından aynı hikaye ve olayların tekrar edilmesiyle tamamlanacaktır. Aslında bunun için 'tamamlamak' yerine, 'gerçeği yeniden üretmek' ifadesini kullanmak daha doğru olabilir, çünkü son bölümdeki çok daha nesnel görünen anlatıcının varlığı bile aslında hikayenin kusursuz biçimde tamamlanmasını sağlayamayacaktır.

Modernizm öncesi anlatılara bakıldığında, Benjy gibi bir karakterin bir romanda böylesine yer kaplayabilmesi, hatta kendine ait bir bölüme sahip olabilmesi şüphesiz mümkün olamazdı. Klasik 
romanın herşeyi bilen güvenilir anlatıcıları, bir zeka özürlünün zihninin içine girmeyi akıllarına getirmezlerdi büyük ihtimalle. Fakat modernist anlatıyla birlikte, geleneksel yöntemlerin geçerliliği ortadan kalkıyordu. Böylelikle, Faulkner gibi modern deneysel estetik üzerine düşünen romancllar, karakterlerinin büyüyüp gelişmesini anlatan ve uzun bir anlatı zamanına yayılan, metnin sonunda da bir sonuca ulaşan olay örgülerinden ve zaman geçtikçe bilinçlenen, okura ders verebilen, kendini örnek aldırabilen karakterlerden büyük ölçüde vazgeçmiştir. Modern okur hiç de öyle başarılı karakterlerle karşı karşıya değildir. Silik, hayatla pek uyuşamayan karakterler modernist edebiyatın antikahramanları olarak artık okurları farklı okuma tecrübelerine davet ederler. Benjy Compson da, bu karakterlerin en uçta duranlardan biridir büyük ihtimalle ve sorgulanan bir zaman kavramı ile karakterlerin içlerinde ne olup bittiğini sürekli anlatılarının merkezine koyan modernist edebiyatın ve modernizmin simgesel bir figürü olarak roman geleneğinin çok önemli bir dönüm noktasıdır.

\section{Kaynakça}

Beja, M. (1971). Epiphany in the Modern Novel. Seattle: University of Washington State.

Burton, S. (1995). "Benjy, Narrativity, and the Coherence of Compson History", Cardozo Studies in Law and Literature, Vol. 7. No:2 (Sonbahar-Kiş, 1995) pp. 207-228.

Butor, M. (1991). Roman Üstüne Denemeler. Çev. Mehmet Rifat; Sema Rifat. İstanbul: Düzlem.

Ecevit, Y. (2001). Türk Romanında Postmodernist Açılımlar. İstanbul: İletişim.

Erbora, A. (1997). Focalization: The Rendering of Consciousness in Henry James' Late Novels. İstanbul: Türk Kütüphaneciler Derneği.

Faulkner, W. (2009). Ses ve Öfke. Çev. Rasih Gürhan. İstanbul: Yapı Kredi.

Gillies, M. (1996). Henri Bergson and British Modernis. London: McGill-Queen's University Press.

James, W. (1950). Principles of Psychology. New York: Dover Publications.

Kern, S. (2003). The Culture of Time and Space. London: Harvard University Press.

Lehrer, J. (2009). Proust Bir Sinirbilimciydi Çev. Ferit Burak Aydar. İstanbul: Boğaziçi Üniversitesi Yayınevi.

Lewis, P. (2007). The Cambridge Introduction to Modernism. Cambridge: Cambridge University Press

Lodge, D. (2002), Consciousness \& The Novel: Connected Essays. Cambridge: Harvard University Press.

Matz, J. (2004). The Modern Novel: A Short Introduction. Oxford: Blackwell Publishing.

Melvin Freidman, M. (1955). Stream of Consciousness: A Study in Literary Method. London: Oxford University Press.

Parla, J. (2000). Don Kişot’tan Bugüne Roman. İstanbul: İletişim.

Ruland, R., Bradbury, M. (1992). From Puritanism to Postmodernism. New York: Penguin Books.

Watt, I. (2007). Romann Yükselişi: Defoe, Richardson ve Fielding Üzerine İncelemeler. Çev. Ferit Burak Aydar. İstanbul: Metis.

Woolf, V. (2007). Mrs. Dalloway. İstanbul: İletişim. 